\title{
Application of Finnish energy saving and emission reduction technology in glass industry
}

\author{
Zhao Pingyuan ${ }^{1, a^{*}}$, Zhang Xiujuan ${ }^{1, b}$ \\ ${ }^{1}$ Art Management Division of Fine Arts Department, College of Arts \& Design of Jimei University, Xiamen, Fujian, \\ China
}

\begin{abstract}
Finland has formed a unique energy saving and emission reduction concept in the process of realizing the leap from agriculture to industrialization, which has been shown in the utilization of raw materials, optimizing fuel structure, recovering waste heat and waste disposal. These concepts and aspects have been widely used in the glass industry, from the early glass technology reform to the present stage of technological innovation for the development of Finnish glass industry to provide an important guarantee. Finland experience provides experience and reference for the development of glass industry in China, which has important strategic significance in the increasingly severe environment of energy crisis.
\end{abstract}

\section{Introduction}

The governments of major western developed countries have experienced a series of changes in the concept of energy conservation and emission reduction. The fundamental trend is to shift from punishment centered policy-making to profit oriented policy-making. Finland's concept of energy conservation and emission reduction is unique. From 2003 to 2005, Finland ranked first in the global competitiveness ranking, surpassing the United States, Japan, Sweden and other countries. Looking back on the development of Finland's industry, from 1900 to 1960, after three wars, Finland's gross national product was about 200 billion euro, with a per capital GDP of 39000 euro. Finland became an industrial power from the poorest agricultural country in Europe. Finland's three pillar industries are forest industry, machinery and metal industry, and high technology. Due to the lack of energy, Finland has many advanced concepts and technologies in energy use and energy saving, which are worth exploring and learning. Since 2017, China's glass industry has actively carried out the application of emission permits. As of January 7, 2021, 4493 glass related enterprises have issued emission permits. Among them, there are 2587 glass manufacturers (C304), 1290 glass products manufacturers (C305) and 616 glass fiber and glass products manufacturers (c3061). During this period, glass enterprises actively promoted cleaner production, implemented upgrading and transformation, strengthened environmental management, and greatly improved the level of green development. But extensive energy saving and emission reduction technology is still an important factor restricting the development of the industry. How to find a breakthrough development direction between vigorously developing industry and effectively using energy? The development of Finnish glass industry provides us with a reference case.

\section{Glass manufacturing and related energy saving and emission reduction technologies in Finland}

\subsection{The development of Finnish glass industry}

In 1917, the Grand Duchy of Finland became independent and became the Republic of Finland.In 1925, the Republic of Finland participated in the International Practical Art Biennale held in Monza, Paris. Although Finland's participation in the conference is small, it shows its attitude and determination to develop practical art. Finns want to let the world know a brand new Finland in this new way. The history of industrial development in Finland is not long, but it can get rapid development in a short period of time, and find the direction of struggle. The importance of industrial design itself is a very important reason. Since 1990, Finland has held a design based on industrial product design every two years.The competition also presented awards for works representing the best industrial products and daily necessities design in Finland. In addition, the Finnish Association of industrial designers, which has more than 200 professional members, has been established every

\footnotetext{
a*Corresponding author: kittyzhangxiu@ $126 . c 0 m$

bzpy032003@126.com
} 
year. The annual industrial designer award is awarded to the members who have made outstanding achievements, thus drawing attention to the responsibilities of designers and related topics in the design field. According to the spirit of establishing regional and global cooperation in environmental protection established by Stockholm environmental conference in 1972, the conference on the protection of the Baltic Sea environment was held twice in Helsinki, Finland, in 1974 and 1962. In order to fulfill Finland's international obligation of lightening the load of the Baltic Sea, the Finnish parliament made a resolution to implement water source protection in 1895. Finnish glass manufacturing industry started in 1955 and held h-55 design exhibition in Helsingborg, Sweden. The exhibition has had a profound impact on the development of Finnish glass manufacturing industry, especially household glass. The Finnish section, designed by Timo salpaneva, has been well received. In 1956, a year after the h-55 exhibition, Iitala introduced the glass landmark "I" series designed by Sarpaneva. The principle of "emphasizing art" in practical glass design indicates the future development trend of Finnish glass. By the 1960s, the traditional "mass production" glass products were no longer competitive in overseas markets. At the 1960 Milan triennial, Tapio introduced a series of cast glass. The technology of making glass into uneven surface is used in Paadarin $\mathbf{J}$ series, so that the cast glass has a more decorative appearance to win new market and business opportunities.After 1960s, onamo Design Association, Finnish foreign trade association and Ministry of trade and industry were established one after another. These organizations put forward new standards and requirements for the applicability of technology, safety of work and environmental quality.

\subsection{Finland's achievements in energy conservation and emission reduction in the industrial field.}

The equipment level of different glass production lines varies greatly, so the cost and quality of glass products also vary greatly. In the long run, high-quality and efficient equipment should be used. In order to improve the quality of glass melt and reduce the energy consumption per unit product, the four main parameters (melting temperature, kiln pressure, excess coefficient of exhaust gas and air, hydraulic pressure) in glass melting process were precisely controlled. In the long-term production practice, Finland has summed up a set of mature energy-saving and emission reduction technologies. In terms of raw materials, nepheline syenite is used to replace $\mathrm{K}$-feldspar to achieve the purpose of alkali saving and energy saving, and good economic benefits have been achieved. Carbon powder is used to replace coal powder additive to enhance the glass whiteness and reduce micro bubbles, and good results have also been achieved. At the same time, the work can be carried out by optimizing the composition of the batch and preheating. After preheating, the glass melting temperature and fuel consumption can be reduced. In terms of optimizing the fuel structure, we should phase out the use of high-carbon inferior fuels and encourage the use of low-carbon clean fuels. For example, the combination of electric power and fossil fuel, electric melting technology has been widely used in the glass industry, reasonable electric energy melting can reduce the furnace top temperature by $20 \sim 50{ }^{\circ} \mathrm{C}$, save more than $5 \%$ of gas, and reduce the emission rate by $50 \%$. In terms of waste heat recovery, thermal equipment in glass production line produces a lot of waste heat resources, most of which are directly discharged, resulting in energy waste. The requirements of waste heat recovery and utilization are to meet the needs of process, economic and reasonable, and environmental protection. It can be used for preheating combustion air, waste heat power generation, hot water and steam production. Waste heat power generation is not only energy saving, but also environmental protection. In terms of waste treatment and utilization, the successful use of flue gas denitration technology refers to the physical and chemical changes of NOx emitted from flue gas, resulting in the formation of non polluting substances such as N2 and water into the atmosphere. Finland adopts SCR (selective catalytic reduction) denitration technology. SCR denitration efficiency can reach more than $70 \%$, NOx emissions fully meet the new standards of many countries for NOx emissions of glass industry.In addition, Finland has world-class wastewater treatment technology and equipment, and the purified water quality meets the standard of ordinary water use. Relevant departments also continuously monitor the water quality through sampling and testing, regularly inspect and maintain the water supply system and sewer pipes, and formulate measures to deal with emergencies.In a word, Finland uses strict laws and regulations, technical standards and advanced technology and process in the production practice, which makes the glass industry develop rapidly while taking into account energy conservation, emission reduction and environmental health, and provides important experience and technical guarantee for the development of the same industry in other countries.

\section{Application of Finnish energy saving and emission reduction innovative technology in glass industry.}

\section{1 burning wooden glass mold: the arrival of the era of technological innovation.}

Timo sarpaneva is the originator of innovative glass technology. In 1964, he tried the possibility of glass decoration, casting and blowing the finland in series. This set of process directly casts the burning glass into the wood mold, the production time is twice as fast as usual, and can produce a surface effect similar to ice crystal. The most impressive demonstration at the 1967 world's fair was the Montreal blown glass sculpture in the Finnish Pavilion. In the $40 \mathrm{~cm}^{2}$ exhibition area, the walls are decorated with a series of glass reliefs, which are used by the designer sarpaneva to display Finland's art industry, wood, metal, textiles, ceramics and glass. 
Salpaneva's new design, ahtojaa (floating ice), was also chosen by the Finnish Pavilion. One of the most influential works of Finnish glass in the world is flindari series. The two long side steel molds of flindari series glass bottles are engraved with the mark of geographical design. F1indari's molds are made of wood with short edges, and the decorative metal parts produce a uniform effect.

\section{2 principle of not discarding}

Iittala is a world-famous Finnish national treasure household brand and a typical representative of Scandinavian design. It represents the perfect unity of function and exquisite beauty. The history of Iitala is an epic of home product design. Design masters such as Alva Alto, Kaj franc and Tapio wirkala have left many handed down works for Iitala and created many product design pioneers. The classic design works are simple, practical and full of artistic sense. Behind these works lies Iitara's design concept: against abandonment. Iitala believes that people have the right to expect that the design they buy can last a lifetime, and today's society has increasingly understood the value of sustainable design. Therefore, at the beginning of the design, Iitala's products take into account the composability, different series can be combined with each other, and can also be harmonious with the existing home environment. After the verification of time, itala believes that its investment in high-quality design has been well rewarded: itala's product line not only has an endless stream of new designs. There are also classic designs that have gone through more than 80 years. It is not easy to make glassware of ideal quality. We must cultivate a large number of craftsmen, master skilled craftsmanship, and have rich knowledge of materials, colors and production methods. At the same time, in each design and production link. We need skilled glass blowers to work closely with designers and other professionals. Today, Iitala's design symbols have long been well-known in the world, but Iitala has always been loyal to its own tradition and constantly innovated in technology and design. We will always pursue creativity and quality, and continue to develop materials, utensils and working methods that are conducive to the ecological environment.

\section{3 technology innovation of sparklike in Finland}

As the world's first argon analyzer for non-destructive detection of inflatable insulating glass, The company has developed a new and unique gas content detection technology, named Gasglass laser, which brings top quality assurance to insulating glass manufacturers pursuing energy saving and high performance. At present, it is the only one in the world that can detect the gas content in the interlayer of inflatable insulating glass with three glass, two cavities and double-sided coating, and realize on-line nondestructive detection. The Gasglass laser analyzer can be integrated with existing production lines for continuous and automatic measurement, providing excellent quality control for insulating glass manufacturers to meet modern production standards. Advanced measurements from Gasglass laser analyzer enable insulating glass manufacturers to get the most measurements before their products leave the factory, ensuring the consistency of high quality. Reliable and continuous measurement results can reduce customer complaints, which is a considerable saving for insulating glass manufacturers.

\section{4 business philosophy of Glaston glass}

Glaston group is a global high-tech group with stable finance and rapid development. It is a listed company in Helsinki, Finland. As the world's leading supplier of glass processing equipment, glastone has decades of $\mathrm{R} \& \mathrm{D}$ experience, advanced technical equipment and the most extensive service outlets. At present, the group has factories in Finland, Italy, the United States, Brazil, Mexico and China, and has more than 30 sales and service organizations around the world. In today's environment, the energy efficiency of glass deep processing enterprises has a decisive impact on the profits of the industry. Energy efficiency can be divided into two main themes: equipment output and energy consumption. In the process of efficient production, the energy cost saved plays an important role in maximizing profits. Through continuous exploration, Glaston has learned a lot about how to improve the energy efficiency of glass deep processing and reduce the energy cost of end products. They believe that even small adjustments and improvements can improve energy efficiency by several percentage points, so as to maximize energy utilization and reduce energy consumption and end product prices as much as possible.

\section{5 perfect national innovation system.}

In the Finnish innovation system, there is an institution that plays a very important role, namely the Finnish National Technology Research Center (VTT). As the largest applied technology research institution in northern Europe, VTT has become an important part of the Finnish national innovation system. Its existence keeps the links of knowledge production, knowledge application and transformation in Finland organic, and makes the links among universities, research institutes, enterprises and other innovation subjects closer. In this stage, VTT follows the national strategy and advances to information technology. At the end of 1980s, Finland's innovation strategy gradually made a breakthrough in the field of information technology, and established nine research institutes of electronics, communication technology, automation, chemical technology, biotechnology and food research, energy, manufacturing technology and construction technology, among which the production of glass industry was also listed. Finland is lack of natural resources, so it is an inevitable choice to choose the way of energy saving. Moreover, the Finnish government has risen to the level of national policy and spared no effort to promote it. Design 2005, the first edition of national design policy issued by the Finnish 
government in 2000, points out that design is not only an industry skill, but also a clean and efficient human knowledge resource. The input of knowledge resources can gradually reduce and replace the consumption and dependence on natural resources, and make the economy achieve sustainable development.[1] In addition to beautifying the environment, the change of design also accelerates the development of production mode, so that the use of materials suitable for the environment in the production process is consistent with the sustainable development. In 2013, the objectives of "Finnish design policy: strategy and action proposal" include: enterprises can obtain the business ability needed for survival in the fierce global competition, provide users with good public services, and take care of Finland's clean natural environment. The proposed vision includes: "by 2020, Finland will achieve international success as a supplier of sustainable, high-quality products and services As a valuable investment, design is widely used in business and design institutions. In the future, new winners in business will benefit from the concepts of experimental methods, responsibility and feedback to nature.[2]

The modern design education system of "the unity of art and technology" has a great influence on the Finnish glass design. Designers trace the value tradition of local culture, study the mentality of advanced design theory, inherit and carry forward the spirit of national craft, advocate the feelings of naturalized art, and constantly promote the development of Finnish glass industry.

\section{Conclusion}

Finland's glass deep processing technology office is the world's leading glass processing industry. Lamino group of Finland is a major supplier of safety glass in northern Europe and one of the largest safety glass production companies in Europe. In the 1990s, the company produced 170000 windscreens per year. In addition, the company's engineering department also provides safety glass production equipment, key design and equipment installation services. Another big company in Finland is TM glas company. Since its establishment in 1870 , it has provided $50 \%$ of the equipment for Europe. The rest is supplied to Far East and North America. Its laminated glass aps-1524 automatic process manufacturing system can realize the cutting, trimming and polishing of automotive windshield glass, The maximum production capacity is 240 pieces per hour, the minimum size is 800 $\mathrm{x} 800 \mathrm{~mm}$, and the maximum size is $1500 * 2400 \mathrm{~mm}$. As we all know, in the glass manufacturing process, from raw materials, melting, molding, processing to the auxiliary processes will produce pollution to the atmosphere, water, soil, and environmental noise. Finland takes the lead in environmental protection and recycling of waste materials. Finland's technology of using waste glass to process new building materials has been popularized all over the world. In 2001, about 40000 tons of waste glass were recycled every year, which brings a broad prospect for the utilization of waste glass. [3] Saving energy and protecting environment are the inevitable trend of the times. In 2019, China's output of flat glass is 930 million weight boxes, accounting for more than $60 \%$ of the global total output. [4]It is pointed out in the report of the 19th National Congress of the Communist Party of China that "building ecological civilization is a millennium plan for the sustainable development of the Chinese nation. We must establish and practice the concept that Lucid waters and lush mountains are invaluable assets, and form a green development mode and life style.". Glass industry is a highly polluting industry. It is not easy to realize green manufacturing."Made in China 2025" clearly pointed out that "support green and clean production, promote the green transformation of traditional manufacturing industry, and promote the establishment of green low-carbon circular development industrial system"[5].In 2021, the government work report of the NPC and CPPCC put forward the "carbon peak" and "carbon neutral" plans. The report points out that the action plan of carbon emission before 2030 should be formulated, so as to optimize the industrial structure and vigorously develop the clean energy industry, so as to better realize the harmonious coexistence of resource and environmental problems and economic development. With the rapid development of the times, China's glass industry has made great progress, but its energy consumption and emissions are still very high. Upgrading new technology of glass industry, adjusting technical structure and developing new melting technology have become the development direction of glass industry in the new century.

\section{Author information}

Zhao Pingyuan: Male, born in 1970 in Jingchuan, Gansu, China; associate professor of College of Arts \& Design of Jimei University; PhD. with research interest in design management and design industry.

\section{References}

1. CHEN Chaojie, FANG Hai. The Finnish Design Based on Sustainable Development Theory[J]. Packaging Engineering, 2014, 35 (6) : 69-72.

2. KÄHÖNEN H, CHEN Chaojie. Research on the Evolution and Development of Design Innovation System in Finland [C]//WANG Xiaohong. China Innovation Design Development Report (2016). Beijing: Social Science Press, 2016.

3. Global outlook of renewable resources research, issue 6: 40 .

4. $\mathrm{Hu}$ Anfeng, Wang Peizhao.(2020)Sustainability of energy conservation and emission reduction in glass industry.Glass enamel and glasses.48(05):40-43.

5. Chen Shaoqiang.(2020) Furniture selection and ecological design based on green manufacturing. Forest products industry, 57 (01) :67-69 